\title{
CHANGES IN REGIONAL UNEMPLOYMENT RATES IN THE CZECH REPUBLIC DURING ECONOMIC CYCLE
}

\author{
Tomas PAVELKA \\ University of Economics, Prague \\ Department of Microeconomics \\ W. Churchill Sq. 4, 13067 Prague 3 \\ Czech Republic \\ E-mail: pavelkat@vse.cz \\ Tomas LÖSTER \\ University of Economics, Prague \\ Department of Statistics and Probability \\ W. Churchill Sq. 4, 13067 Prague 3 \\ Czech Republic \\ E-mail: losterto@vse.cz \\ doi:10.13165/IE-13-7-4-06
}

\begin{abstract}
The Czech economy has been hit by the economic recession in recent years. Relatively strong economic growth and then economic downturn also had a significant impact on the labour market. The development of the unemployment rates - total, for women and men, however, showed significant differences between regions and districts of the Czech Republic. The article examines whether the differences in the unemployment rates in the regions and districts of the Czech Republic deepened or not during the economic crisis. The widening gap between regions can be a sign of decreasing flexibility of the Czech labour market. The article first briefly describes the recent economic development of the Czech economy. The end of the article is devoted to the comparison of the unemployment rate in the Czech Republic with other Member States of the European Union.
\end{abstract}

JEL classification: J23, 164.

Keywords: economic crisis, flexibility of labour market, unemployment rate.

Reikšminiai žodžiai: ekonominè krizé, darbo rinkos lankstumas, nedarbo lygis.

\section{Introduction}

Unemployment has come again to the attention of economists and politicians during the last few years. The unemployment rates in the context of the recent economic recession and the debt crisis in some countries set long-term records. High unemploy- 
ment is associated with a number of negative effects, which affect not only unemployed individuals, but also whole economies. The negative economic development is also apparent in the Czech economy. The economic recession has had an impact on the Czech labour market. Unemployment has grown and the proportion of long-term unemployed people has increased, too. The development of long-term unemployment according to different groups of the population broken down by educational attainment, sex and age are described in detail in the book Dlouhodobá nezaměstnanost v České republice [Longterm Unemployment in the Czech Republic] (Pavelka, Löster, Makovský, Langhamrová, 2011). A growing number of unemployed people has also led to the attempts to calculate the negative impact of unemployment, e.g., the study called Odhad nákladì nezaměstnanosti $z$ pohledu veřejných rozpočtu [Unemployment Cost Estimate from Public Budgets Perspective] (Čadil, Pavelka, Kaňková, Vorlíček, 2011) tried to calculate the impact of unemployment in terms of the public budgets of the Czech Republic.

The unemployment rate has not changed in all regions of the Czech Republic uniformly. The aim of this article is to describe regional differences in the unemployment rate in the Czech Republic. In the first part of the article, the latest development of the Czech economy is described. Attention is paid to the development of real gross domestic product and the unemployment rate. The second part is devoted to regional differences in unemployment rates - total, of women and men. First, the development of unemployment rates in regions of the Czech Republic is described. Subsequently, the indicators that characterize regional differences between smaller units of the Czech Republic - districts - are calculated. Particular attention is paid to whether the regional differences in unemployment deepened during the economic recession. The continuing and possibly expanding regional differences in unemployment rates may be a sign of low labour mobility. In the case of high flexibility (including the mobility of the labour force), regional disparities should be declining. The last part of the article is devoted to a comparison of the unemployment rate in the Czech Republic with other European Union Member States.

Unless stated otherwise, in the article the registered unemployment rates to the end of particular years are used. These unemployment rates are published by the Ministry of Labour and Social Affairs of the Czech Republic on the basis of data from various branches of the Labour Office. The registered unemployment rate is not internationally comparable. Thus, to compare rates in the European Union, the internationally comparable unemployment rate as calculated by the Labour Force Survey is used.

\section{The development of the Czech economy}

Like most European countries, in recent years the Czech Republic has gone through the economic cycle. Between 2006 and 2007, the Czech Republic reached one of the highest rates of real gross domestic product in the European Union. As can be seen in Figure 1, in 2006 the gross domestic product grew by $7.0 \%$ and in 2007 by $5.7 \%$. In 2006, all main expenditure components of gross domestic product, excluding government final consumption expenditure, positively influenced the total growth. In 2007, the rate of export growth declined, and exports grew slower than imports in annual comparison. Other items of 
expenditure led to an overall positive growth of gross domestic product. The gross fixed capital formation had the fastest growth (13.2\%) this year. The Czech Republic is a small open economy, so it was only a matter of time when the global economic recession affected the Czech economy, too. For the first time, the Czech economy fell in the last quarter of 2008. In summary, the 2008 gross domestic product of the Czech Republic increased year on year by $3.1 \%$. For the whole year, all major expenditure components of gross domestic product still grew, although the growth rates were low. In 2009, the global economic recession hit the Czech economy with full force, and the gross domestic product dropped by $4.5 \%$. The negative development of investment and foreign trade were the main causes of this decline. Gross capital formation decreased by more than $20 \%$, and fixed gross capital formation and changes in inventories had the largest effect. Exports fell by $10.9 \%$ and imports by $12.1 \%$. Government spending worked counter-cyclically and household consumption stagnated this year. Based on data from 2010, it seemed that the recession had only a short duration, since gross domestic product grew by $2.5 \%$ this year. Exports and imports grew identically by more than $15 \%$. There were slight recoveries in gross fixed capital formation and household consumption, but government spending stagnated. In 2011, the Czech government, under the influence of the European debt crisis, began to reduce the fiscal deficit by reducing their expenses. Government final consumption expenditure decreased by $2.7 \%$. The rate of real gross domestic product was only $1.8 \%$. Government savings, the appropriateness of which is still being debated, contributed to the negative expectations of households about the future. Household final consumption fell by $2.2 \%$ in 2012. It was the first decline of household consumption since 1998. In 2012, the government continued in its cuts, and government final consumption expenditure decreased by $1.9 \%$. The government savings have negatively influenced the investment expenditures of firms, too. Gross fixed capital formation fell by $4.5 \%$. The positive contribution of foreign trade did not exceed the negative impact of households, governments and companies expenditures. Overall, the Czech Republic's gross domestic product fell by $1.0 \%$ in 2012.

The development of real gross domestic product influenced the labour market. In this article, the authors concentrate only on the unemployment rate. The unemployment rates in the Czech Republic for the period of 2007-2012 are presented in Figure 2. It is well known that the unemployment rate responds to changes in the gross domestic product with a certain delay. This fact is evident from a comparison of the data in Figures 1 and 2 only partly because of using annual averages for GDP and unemployment rates at the end of the years.

The rapid growth of real gross domestic product resulted in a decrease in the unemployment rate. In 2007, the total unemployment was $5.98 \%$, the unemployment rate of women was $7.38 \%$ and the unemployment rate of men was $4.92 \%$. The unemployment rate of women was lower by 0.17 percentage points and the unemployment rate of men was by 0.2 percentage points higher in 2008. A significant decline in real output led to a rapid rise in unemployment in 2009, the total unemployment rate rose to $9.24 \%$. In 2009 , the unemployment rate of women increased by 3.12 percentage points and the unemployment rate of men increased by 3.42 percentage points. The unemployment rate continued to grow in 2010 , despite the renewed growth of the gross domestic product. In 2010, the total unemployment rate was $9.57 \%$, the unemployment rate of women was $10.65 \%$ and the unem- 
ployment rate of men was $8.76 \%$. From Figure 2, it is obvious that all three unemployment rates slightly decreased in 2011. But the negative economic development during the last years resulted in increase of all three unemployment rates. The total unemployment rate increased by 0.74 percentage points, the unemployment rate of women by 0.72 percentage points and the unemployment rate of men by 0.75 percentage points.

Figure 1. Real gross domestic product of the Czech Republic (annual change)

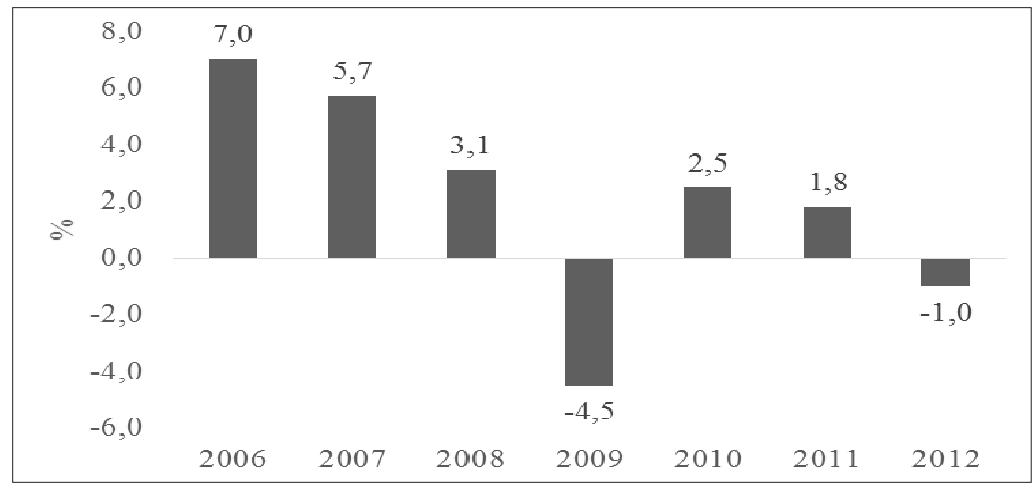

Source: Czech Statistical Office (2013a)

Figure 2. Unemployment rate in the Czech Republic (\%, end of the year)

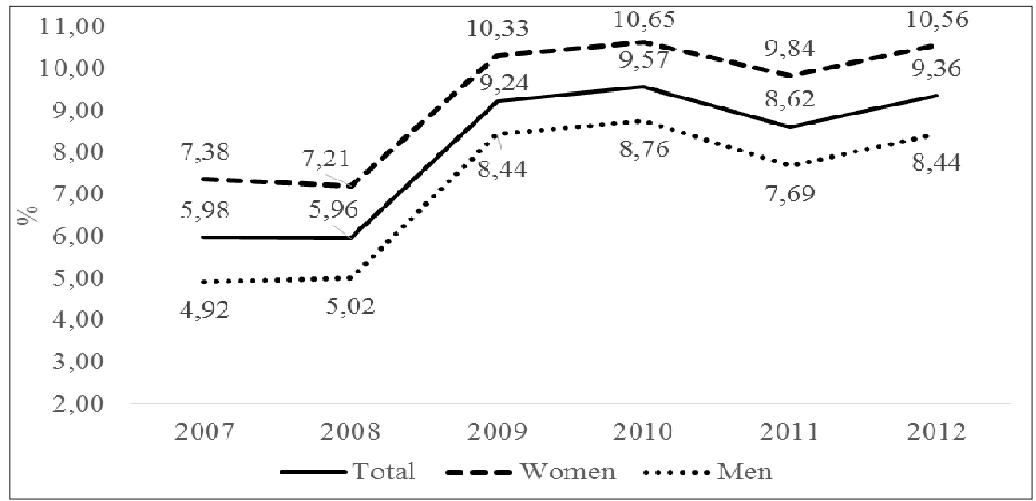

Source: Czech Statistical Office (2013b)

\section{Regional differences in unemployment rate in the Czech Republic}

The unemployment rate in the Czech Republic shows considerable regional differences. First, attention will be paid to the regions of the Czech Republic and later to the 
districts. In the Czech Republic, there are 14 regions totally. The development of total, women and men rates of unemployment in the regions of the Czech Republic is shown in Tables 1 to 3. Tables 4 to 6 contain the annual changes in the unemployment rates in different regions of the Czech Republic.

Table 1. Total unemployment rates in the regions of the Czech Republic (\%, end of the year)

\begin{tabular}{|l|c|c|c|c|c|c|}
\hline & $\mathbf{2 0 0 7}$ & $\mathbf{2 0 0 8}$ & $\mathbf{2 0 0 9}$ & $\mathbf{2 0 1 0}$ & $\mathbf{2 0 1 1}$ & $\mathbf{2 0 1 2}$ \\
\hline Praha & 2,2 & 2,1 & 3,7 & 4,1 & 4,0 & 4,5 \\
\hline Středočeský kraj & 4,3 & 4,5 & 7,0 & 7,7 & 7,1 & 7,5 \\
\hline Jihočeský kraj & 4,5 & 4,8 & 7,8 & 8,5 & 7,5 & 8,4 \\
\hline Plzeňský kraj & 4,4 & 5,0 & 8,2 & 8,3 & 7,0 & 7,3 \\
\hline Karlovarský kraj & 7,3 & 5,0 & 11,1 & 11,4 & 9,8 & 10,8 \\
\hline Ústecký kraj & 11,0 & 10,3 & 13,6 & 13,9 & 12,9 & 14,0 \\
\hline Liberecký kraj & 6,1 & 7,0 & 11,2 & 10,5 & 9,5 & 10,3 \\
\hline Královéhradecký kraj & 4,7 & 4,8 & 8,0 & 8,4 & 7,5 & 8,6 \\
\hline Pardubický kraj & 5,4 & 6,0 & 9,6 & 9,9 & 8,4 & 9,2 \\
\hline Vysočina & 5,6 & 6,3 & 10,3 & 10,7 & 9,4 & 10,2 \\
\hline Jihomoravský kraj & 6,9 & 6,8 & 10,6 & 10,9 & 9,8 & 10,4 \\
\hline Olomoucký kraj & 6,7 & 6,9 & 12,2 & 12,5 & 11,4 & 11,9 \\
\hline Zlínsky kraj & 6,0 & 6,1 & 10,8 & 10,7 & 9,4 & 10,4 \\
\hline Moravskoslezský kraj & 9,6 & 8,5 & 12,1 & 12,4 & 11,2 & 12,3 \\
\hline
\end{tabular}

Source: Czech Statistical Office (2013b)

As can be seen in Table 1, Prague, the capital, shows the lowest total unemployment rate, and Ústecký Kraj shows the highest in all monitored years. The average total unemployment rate in Prague for the entire period was 3.4\%, but in Ústecký kraj, it was 12.6\%. On average, the difference between the highest and the lowest unemployment rates was 9.2 percentage points. From the data of Table 1, it is apparent that there was nearly no change in this difference during the monitored years. From this fact, it can be said that the regional mobility and, thus, flexibility of the labour force in the Czech Republic is not high enough to ensure the elimination of regional differences in unemployment rates. Plzeňský kraj and Středočeský kraj have also relatively low unemployment rates. Středočeský kraj surrounds Prague and so a lot of people from this region commute to work in Prague. Škoda, the largest Czech car manufacturer, which is a major employer, is also located in this region.

Next to Ústecký kraj, Moravskoslezský kraj has also had persistently high rates of unemployment. Both regions have a similar history. After the revolution in 1989, mining (brown coal in Ústecký kraj and hard coal in Moravskoslezský kraj) and generally heavy industry were reduced. The structural nature of unemployment dominates in both these regions. 
Table 2. Unemployment rates of women in the regions of the Czech Republic (\%, end of the year)

\begin{tabular}{|l|c|c|c|c|c|c|}
\hline & $\mathbf{2 0 0 7}$ & $\mathbf{2 0 0 8}$ & $\mathbf{2 0 0 9}$ & $\mathbf{2 0 1 0}$ & $\mathbf{2 0 1 1}$ & $\mathbf{2 0 1 2}$ \\
\hline Praha & 2,5 & 2,5 & 4,1 & 4,7 & 4,6 & 5,2 \\
\hline Stř̌edočeský kraj & 5,6 & 5,6 & 8,2 & 9,1 & 8,5 & 8,8 \\
\hline Jihočeský kraj & 5,7 & 5,9 & 8,9 & 9,4 & 8,6 & 9,4 \\
\hline Plzeňský kraj & 5,5 & 6,2 & 9,7 & 9,3 & 8,2 & 8,7 \\
\hline Karlovarský kraj & 8,4 & 8,5 & 11,9 & 12,0 & 10,7 & 11,4 \\
\hline Ústecký kraj & 13,7 & 12,9 & 16,4 & 16,5 & 15,2 & 16,7 \\
\hline Liberecký kraj & 7,7 & 8,4 & 13,0 & 12,5 & 11,5 & 12,1 \\
\hline Královéhradecký kraj & 5,7 & 5,6 & 8,7 & 9,2 & 8,2 & 9,3 \\
\hline Pardubický kraj & 6,7 & 7,1 & 10,4 & 10,3 & 9,4 & 10,1 \\
\hline Vysočina & 7,0 & 7,7 & 11,1 & 11,6 & 10,8 & 11,8 \\
\hline Jihomoravský kraj & 8,6 & 8,5 & 11,7 & 11,6 & 11,0 & 11,9 \\
\hline Olomoucký kraj & 8,4 & 8,3 & 13,0 & 13,8 & 12,7 & 13,0 \\
\hline Zlínsky kraj & 7,5 & 7,3 & 11,5 & 11,6 & 10,5 & 11,6 \\
\hline Moravskoslezský kraj & 11,7 & 10,2 & 13,2 & 13,6 & 12,6 & 13,3 \\
\hline
\end{tabular}

Source: Czech Statistical Office (2013b)

From Table 2 and Table 3, it is obvious that the highest unemployment rates of women and men were also in Ustecký kraj and the lowest unemployment rates were in Praha. In Ustecký kraj, the average unemployment rate of women for the given time period is $15.3 \%$ and the unemployment rate of men is $10.7 \%$. In Prague, the average unemployment rate of women is $3.9 \%$ and the average unemployment rate of men is $3.0 \%$.

Table 3. Unemployment rates of men in the regions of the Czech Republic (\%, end of the year)

\begin{tabular}{|l|c|c|c|c|c|c|}
\hline & $\mathbf{2 0 0 7}$ & $\mathbf{2 0 0 8}$ & $\mathbf{2 0 0 9}$ & $\mathbf{2 0 1 0}$ & $\mathbf{2 0 1 1}$ & $\mathbf{2 0 1 2}$ \\
\hline Praha & 1,9 & 1,9 & 3,3 & 3,6 & 3,5 & 4,0 \\
\hline Stř̌edočeský kraj & 3,3 & 3,7 & 6,2 & 6,8 & 6,1 & 6,6 \\
\hline Jihočeský kraj & 3,6 & 4,0 & 6,9 & 7,8 & 6,7 & 7,6 \\
\hline Plzeňský kraj & 3,6 & 4,1 & 7,0 & 7,5 & 6,1 & 6,3 \\
\hline Karlovarský kraj & 6,5 & 6,9 & 10,4 & 10,9 & 9,2 & 10,4 \\
\hline Ústecký kraj & 8,9 & 8,4 & 11,7 & 12,1 & 11,3 & 12,1 \\
\hline Liberecký kraj & 4,9 & 5,9 & 10,0 & 9,1 & 8,0 & 8,8 \\
\hline Královéhradecký kraj & 3,9 & 4,2 & 7,4 & 7,8 & 7,0 & 8,1 \\
\hline Pardubický kraj & 4,5 & 5,1 & 9,0 & 9,6 & 7,7 & 8,4 \\
\hline Vysočina & 4,6 & 5,3 & 9,6 & 10,1 & 8,4 & 9,1 \\
\hline Jihomoravský kraj & 5,6 & 5,6 & 9,7 & 10,3 & 8,9 & 9,3 \\
\hline Olomoucký kraj & 5,5 & 5,8 & 11,6 & 11,5 & 10,4 & 11,0 \\
\hline Zlínsky kraj & 4,9 & 5,2 & 10,3 & 10,1 & 8,5 & 9,5 \\
\hline Moravskoslezský kraj & 8,1 & 7,3 & 11,4 & 11,5 & 10,1 & 11,6 \\
\hline
\end{tabular}

Source: Czech Statistical Office (2013b) 
Table 4. Annual differences between total unemployment rates in the regions of the Czech Republic (in percentage points)

\begin{tabular}{|l|c|c|c|c|c|}
\hline & $\mathbf{2 0 0 8}$ & $\mathbf{2 0 0 9}$ & $\mathbf{2 0 1 0}$ & $\mathbf{2 0 1 1}$ & $\mathbf{2 0 1 2}$ \\
\hline Praha & 0,0 & 1,5 & 0,4 & $-0,1$ & 0,6 \\
\hline Středočeský kraj & 0,2 & 2,5 & 0,7 & $-0,7$ & 0,4 \\
\hline Jihočeský kraj & 0,4 & 3,0 & 0,7 & $-1,0$ & 0,8 \\
\hline Plzeňský kraj & 0,6 & 3,1 & 0,1 & $-1,2$ & 0,3 \\
\hline Karlovarský kraj & $-2,3$ & 6,0 & 0,3 & $-1,6$ & 1,0 \\
\hline Ústecký kraj & $-0,7$ & 3,3 & 0,3 & $-1,0$ & 1,1 \\
\hline Liberecký kraj & 0,9 & 4,3 & $-0,7$ & $-1,1$ & 0,8 \\
\hline Královéhradecký kraj & 0,1 & 3,2 & 0,4 & $-0,9$ & 1,1 \\
\hline Pardubický kraj & 0,5 & 3,6 & 0,3 & $-1,4$ & 0,7 \\
\hline Vysočina & 0,6 & 4,0 & 0,5 & $-1,3$ & 0,8 \\
\hline Jihomoravský kraj & $-0,1$ & 3,8 & 0,3 & $-1,1$ & 0,6 \\
\hline Olomoucký kraj & 0,1 & 5,3 & 0,3 & $-1,1$ & 0,5 \\
\hline Zlínsky kraj & 0,1 & 4,7 & $-0,1$ & $-1,4$ & 1,1 \\
\hline Moravskoslezský kraj & $-1,1$ & 3,7 & 0,2 & $-1,2$ & 1,2 \\
\hline
\end{tabular}

Source: Own callculation

As can be seen in Table 5, in 2008, the total unemployment rate in some regions fell and in some regions increased, and in Prague the total unemployment rate remained the same. The largest declines occurred in Moravskoslezský Kraj and in Ustecký kraj, i.e., in regions with the highest unemployment rates. In contrast, the highest increase was in Plzeňský kraj and Liberecký kraj. In 2009, the total unemployment rate in the Czech Republic increased by 3.2 percentage points. The highest increase of the unemployment rates were in Karlovarský kraj and Olomoucký kraj. The total unemployment rate in the Czech Republic rose by 0.33 percentage points in 2010. In four regions, unemployment rates increased more in 2010, in comparison with the total unemployment rate in the Czech Republic. Liberecky kraj and Zlínský kraj had lower total unemployment rates in 2010 on year on year basis. In 2011, the average unemployment rate in the Czech Republic decreased by nearly 1 percentage point to $8.6 \%$. The unemployment rate fell in all regions of the Czech Republic. The largest decline in the unemployment rate in 2011 compared to 2010 can be seen in Karlovarský kraj, Pardubický kraj and Zlínský kraj. In 2012, the total unemployment rate increased by 0.7 percentage points to $9,4 \%$. A further decline in the unemployment rate was prevented by the return of the economic recession. At the end of the year, the total unemployment rates were higher in all regions of the Czech Republic in 2012 compared to 2011. 
Table 5. Annual differences between unemployment rates of women in the regions of the Czech Republic (in percentage points)

\begin{tabular}{|l|c|c|c|c|c|}
\hline & $\mathbf{2 0 0 8}$ & $\mathbf{2 0 0 9}$ & $\mathbf{2 0 1 0}$ & $\mathbf{2 0 1 1}$ & $\mathbf{2 0 1 2}$ \\
\hline Praha & 0,0 & 1,6 & 0,6 & $-0,1$ & 0,6 \\
\hline Středočeský kraj & 0,1 & 2,6 & 0,9 & $-0,6$ & 0,3 \\
\hline Jihočeský kraj & 0,2 & 3,1 & 0,5 & $-0,8$ & 0,8 \\
\hline Plzeňský kraj & 0,7 & 3,5 & $-0,4$ & $-1,1$ & 0,5 \\
\hline Karlovarský kraj & 0,1 & 3,4 & 0,1 & $-1,3$ & 0,8 \\
\hline Ústecký kraj & $-0,8$ & 3,5 & 0,1 & $-1,3$ & 1,5 \\
\hline Liberecký kraj & 0,7 & 4,6 & $-0,5$ & $-1,0$ & 0,7 \\
\hline Královéhradecký kraj & $-0,1$ & 3,1 & 0,5 & $-1,0$ & 1,2 \\
\hline Pardubický kraj & 0,4 & 3,3 & $-0,1$ & $-0,9$ & 0,8 \\
\hline Vysočina & 0,6 & 3,5 & 0,4 & $-0,8$ & 0,9 \\
\hline Jihomoravský kraj & $-0,1$ & 3,3 & $-0,1$ & $-0,7$ & 0,9 \\
\hline Olomoucký kraj & $-0,2$ & 4,8 & 0,7 & $-1,1$ & 0,3 \\
\hline Zlínsky kraj & $-0,2$ & 4,2 & 0,1 & $-1,2$ & 1,1 \\
\hline Moravskoslezský kraj & $-1,5$ & 3,0 & 0,4 & $-0,9$ & 0,7 \\
\hline
\end{tabular}

Source: Own calculation

Table 6. Annual differences between unemployment rates of men in the regions of the Czech Republic (in percentage points)

\begin{tabular}{|l|c|c|c|c|c|}
\hline & $\mathbf{2 0 0 8}$ & $\mathbf{2 0 0 9}$ & $\mathbf{2 0 1 0}$ & $\mathbf{2 0 1 1}$ & $\mathbf{2 0 1 2}$ \\
\hline Praha & 0,0 & 1,5 & 0,3 & $-0,1$ & 0,6 \\
\hline Stř̌edočeský kraj & 0,4 & 2,5 & 0,6 & $-0,7$ & 0,5 \\
\hline Jihočeský kraj & 0,5 & 2,9 & 0,9 & $-1,1$ & 0,9 \\
\hline Plzeňský kraj & 0,5 & 2,9 & 0,4 & $-1,3$ & 0,2 \\
\hline Karlovarský kraj & 0,4 & 3,5 & 0,5 & $-1,8$ & 1,2 \\
\hline Ústecký kraj & $-0,6$ & 3,3 & 0,4 & $-0,8$ & 0,8 \\
\hline Liberecký kraj & 1,0 & 4,1 & $-0,8$ & $-1,1$ & 0,9 \\
\hline Královéhradecký kraj & 0,3 & 3,2 & 0,3 & $-0,8$ & 1,1 \\
\hline Pardubický kraj & 0,7 & 3,9 & 0,6 & $-1,8$ & 0,7 \\
\hline Vysočina & 0,7 & 4,3 & 0,5 & $-1,7$ & 0,7 \\
\hline Jihomoravský kraj & 0,0 & 4,1 & 0,5 & $-1,4$ & 0,4 \\
\hline Olomoucký kraj & 0,4 & 5,7 & 0,0 & $-1,2$ & 0,6 \\
\hline Zlínsky kraj & 0,4 & 5,1 & $-0,3$ & $-1,6$ & 1,0 \\
\hline Moravskoslezský kraj & $-0,8$ & 4,1 & 0,1 & $-1,4$ & 1,5 \\
\hline
\end{tabular}

Source: Own calculation

The unemployment rates of women and men increased in all regions of the Czech Republic in 2009. The highest increase was achieved in Olomoucký kraj, the unemployment rate of men increased by 5.7 percentage points and the unemployment rate of women increased by 4.8 percentage points. The lowest increase can be seen in Prague, 
the unemployment rate of men increased by 1.5 percentage points and the unemployment rate of women increased by 1.6 percentage points.

The unemployment rate of men decreased in two regions and the unemployment rate of women decreased in four regions of the Czech Republic in 2010 compared to 2009. Slight recovery caused the decrease of unemployment rates of women and men in all the regions in 2011. But the return of recession led to higher unemployment rates of women and men in all the regions of the Czech Republic in 2012.

\section{Regional disparities in districts of the Czech Republic}

There are data about the registered unemployment rate in the Czech Republic in individual districts, too. The Czech Republic is divided into 14 regions and each region is further divided into districts ${ }^{1}$ for the calculation of the unemployment rate (and not only for this purpose.)

Tables 7 to 9 contain the basic indicators, which can be used for the expression of the regional disparities of the unemployment rates among districts of the Czech Republic. The minimum and the maximum unemployment rates, range, standard deviation and the coefficient of variation are used. In fact, these indicators are used by the Organization for Economic Cooperation and Development for assessing of regional disparities in unemployment rates, too (OECD, 2005).

Table 7. Indicators of regional disparities of the total unemployment rates in the Czech Republic -districts

\begin{tabular}{|l|c|c|c|c|c|c|}
\hline & $\mathbf{2 0 0 7}$ & $\mathbf{2 0 0 8}$ & $\mathbf{2 0 0 9}$ & $\mathbf{2 0 1 0}$ & $\mathbf{2 0 1 1}$ & $\mathbf{2 0 1 2}$ \\
\hline Minimum (\%) & 1,6 & 1,8 & 3,4 & 4,1 & 3,3 & 3,6 \\
\hline Maximum (\%) & 15,5 & 13,1 & 16,9 & 19,7 & 16,8 & 18,0 \\
\hline Range (p.p.) & 13,9 & 11,3 & 13,5 & 15,6 & 13,5 & 14,4 \\
\hline Standard deviation & 2,8 & 2,4 & 3,0 & 3,0 & 2,9 & 2,9 \\
\hline Coeff. of variation (\%) & 43,7 & 37,1 & 29,4 & 29,1 & 30,8 & 29,1 \\
\hline
\end{tabular}

Source: Own calculation

From Table 7, it is clear that in the Czech Republic there are significant differences in total unemployment rates among districts. The differences in total unemployment rates between the district with the lowest and with the highest rates were between 15.6 percentage points (in 2010) and 11.3 percentage points (in 2008). As it can be noticed from Table 7, it is also clear that if the overall unemployment rate decreases, there is a decrease in regional disparities, as well. It follows that when the overall unemployment rate fell, in the district with the highest rate it decreased more than in the district with the lowest

1 Officially, the Czech Republic is divided into 14 regions and 6253 municipalities. Statisticians, however, for some purposes still use districts, which were officially abolished in 2003. Overall, the Czech Republic is divided into 77 districts; one of them is the capital city of Prague. 
rate. Conversely, when the overall unemployment rate increases, the range increases, too. Also, from the standard deviation it is evident that regional disparities decrease when the overall unemployment rate decreases. The lowest unemployment rates can be found in districts that are close to the capital and in Prague itself. On the contrary, the highest unemployment rates can be noticed in districts, which are part of regions Ústecký kraj and Moravskoslezský kraj, thus, in regions that had the highest unemployment rates.

From Table 8, it is obvious that the unemployment rates of women showed higher differences than the total unemployment. The range between the highest and the lowest unemployment rates were between 17.5 percentage points (in 2007) and 13.3 percentage points (in 2008). In the case of women, the same development of variability as in the case of the total unemployment can be seen. The lower unemployment rate, the lower variability, and vice versa.

Table 8. Indicators of regional disparities of the unemployment rates of women in the Czech Republic -districts

\begin{tabular}{|l|c|c|c|c|c|c|}
\hline & $\mathbf{2 0 0 7}$ & $\mathbf{2 0 0 8}$ & $\mathbf{2 0 0 9}$ & $\mathbf{2 0 1 0}$ & $\mathbf{2 0 1 1}$ & $\mathbf{2 0 1 2}$ \\
\hline Minimum (\%) & 2,1 & 2,3 & 4,0 & 4,7 & 4,1 & 4,2 \\
\hline Maximum (\%) & 19,6 & 15,6 & 20,9 & 21,3 & 18,9 & 20,6 \\
\hline Range (p.p.) & 17,5 & 13,3 & 16,9 & 16,6 & 14,8 & 16,4 \\
\hline Standard deviation & 3,4 & 3,0 & 3,4 & 3,4 & 3,2 & 3,3 \\
\hline Coeff. of variation (\%) & 43,7 & 37,7 & 29,8 & 29,3 & 30,2 & 28,9 \\
\hline
\end{tabular}

Source: Own calculation

Table 9 contains the basic indicators of regional disparities in the case of unemployment rate of men in the Czech Republic. The unemployment rates of men were lower than the total unemployment rates and the unemployment rates of women, too. The variability is also the lowest in the case of the unemployment rates of men. The range between the highest and the lowest unemployment rates was between 15.1 percentage points (in 2010) and 9.5 percentage points (in 2008). Also, standard deviation was lower in all the years in the case of women if compared to men. But coefficient of variation was higher in the case of men.

Table 9. Indicators of regional disparities of the unemployment rates of men in the Czech Republic -districts

\begin{tabular}{|l|c|c|c|c|c|c|}
\hline & $\mathbf{2 0 0 7}$ & $\mathbf{2 0 0 8}$ & $\mathbf{2 0 0 9}$ & $\mathbf{2 0 1 0}$ & $\mathbf{2 0 1 1}$ & $\mathbf{2 0 1 2}$ \\
\hline Minimum (\%) & 1,3 & 1,5 & 3,0 & 3,5 & 2,8 & 3,1 \\
\hline Maximum (\%) & 12,5 & 11,0 & 16,4 & 18,6 & 15,4 & 17,4 \\
\hline Range (p.p.) & 11,2 & 9,5 & 13,4 & 15,1 & 12,6 & 14,3 \\
\hline Standard deviation & 2,3 & 2,1 & 2,8 & 2,9 & 2,7 & 2,8 \\
\hline Coeff. of variation (\%) & 45,3 & 37,8 & 30,5 & 30,5 & 32,2 & 30,8 \\
\hline
\end{tabular}

Source: Own calculation 


\section{Unemployment in the Czech Republic and other Member States of the European Union}

For an overall assessment of the situation on the Czech labour market, it is appropriate to compare the unemployment rate in the Czech Republic with other Member States of the European Union. Figure 3 depicts the unemployment rates across the European Union in 2008, and Figure 4 presents the unemployment rates in 2012. These unemployment rates were calculated by national statistical offices through the Labour Force Survey.

The unemployment rate in the Czech Republic is traditionally below the European Union average. In 2008, the unemployment rate in the European Union ranged between $2.7 \%$ in the Netherlands and $11.4 \%$ in Spain. The European Union's average of the unemployment rate was $7.1 \%$. The unemployment rate in the Czech Republic was only $4.4 \%$ and it was the fifth lowest rate in the European Union rate in 2008.

During the economic crisis, the unemployment rate in the whole Europe increased. Slow economic growth during the last years was not sufficient to reduce the unemployment rate back to the rates of 2008. In 2012, the average unemployment rate in the European rate was $10.6 \%$, i.e. higher by 3.5 percentage points than in 2008 . The unemployment rate ranged between $4.4 \%$ in Austria and $25.2 \%$ in Spain. In the Czech Republic, the unemployment rate was $7 \%$ (an increase by 2.6 percentage points) in 2012 . Also, in 2012, the unemployment rate in the Czech Republic was the fifth lowest rate in the European Union.

Figure 3. Unemployment rate in the EU in 2008

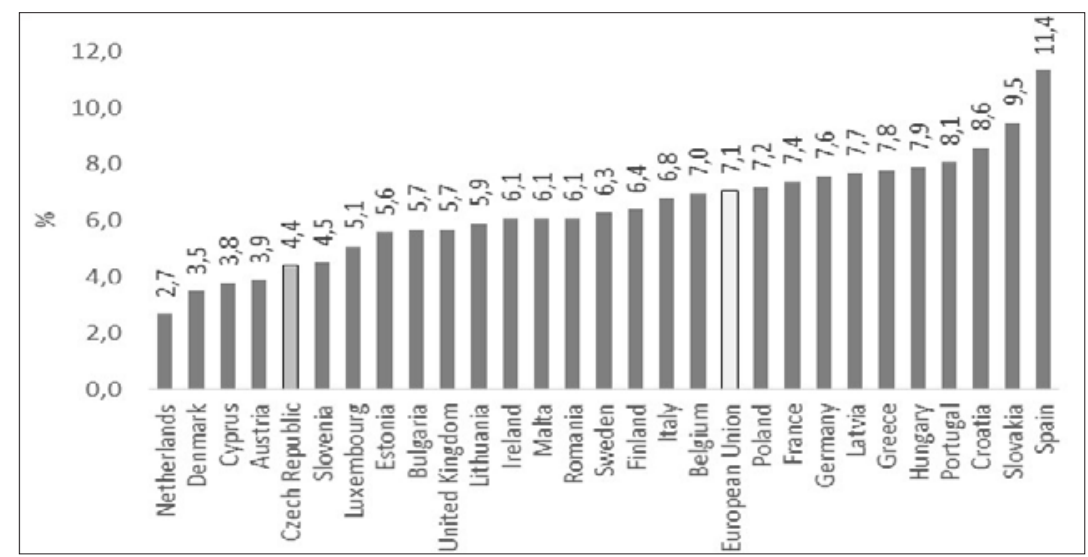

Source: Eurostat (2013) 
Figure 4. Unemployment rate in the EU in 2012

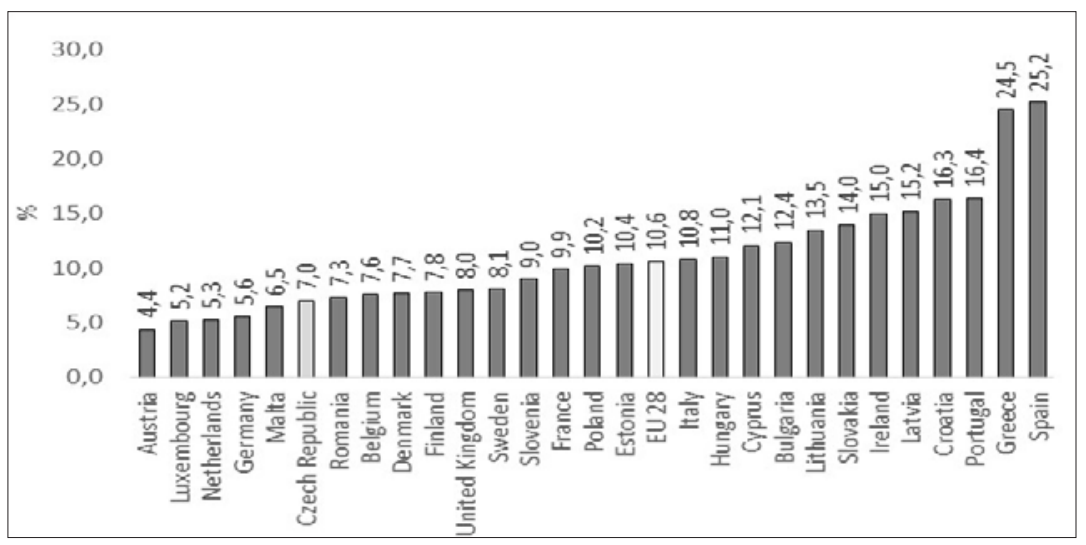

Source: Eurostat (2013)

\section{Conclusion}

The Czech economy was hit by the economic crisis like the most of the European countries in 2008-2009. However, unlike some Member States, the Czech Republic was in recession last year, too. One of the reasons was inadequate policy of budget cuts that weakened the private consumption and investments of firms. The economic decline was also reflected in the labour market, the unemployment rate increased substantially. In comparison with the rest of the Member States of the European Union, the unemployment rate in the Czech Republic is one of the lowest. The problem of unemployment in the Czech Republic is related to considerably regional disparities. These disparities became even larger during the economic crisis. There was a bigger increase of the unemployment rate in the regions that had a higher rate of unemployment before crisis, and vice versa. Persistent regional differences in unemployment rates may indicate that labour mobility, and therefore, its flexibility are not sufficient.

The article is one of the outputs from the research project "Flexibilita trhu práce České republiky" registered with the University of Economics, Prague, under the number IGS MF/19/2012. The article is modified and it is an extended version of the conference paper "The Impact of Economic Crisis on Regional Unemployment Rates in the Czech Republic", which was presented at the Whither Our Economies 2013.

\section{References}

1. Čadil, J.; Pavelka, T.; Kaňková, E.; Vorlíček, J. Odhad nákladů nezaměstnanosti z pohledu veřejných rozpočtů. Politická ekonomie. 2011, 59(5): 618-637. 
2. Czech Statistical Office. Macroeconomic Indicators. 2013a [interactive]. [accessed on 20-11-2013]. <http://www.czso.cz/eng/redakce.nsf/i/macroeconomic_indicators/\$File/ AHLMAKRO.xls $>$.

3. Czech Statistical Office. Time Series of Basic Statistical Indicators of Labour. 2013b [interactive]. [accessed on 20-11-2013]. <http://www.czso.cz/csu/2013edicniplan. nsf/publ/3107-13-p1_2013>.

4. Eurostat. Employment and Unemployment Database. 2013 [interactive]. [accessed on 15-09-2013]. <http://epp.eurostat.ec.europa.eu/portal/page/portal/employment_unemployment_lfs/data/database $>$.

5. OECD. OECD Employment Outlook. 2005 [interactive]. [accessed on 15-09-2013]. $<$ http://www.oecd.org/els/emp/36780856.pdf>.

6. Pavelka, T.; Löster, T.; Makovský, P.; Langhamrová, J. Dlouhodobá nezamměstnanost v České republice. Slaný: Melandrium, 2011.

\section{REGIONINIO NEDARBO KITIMAS ČEKIJOS RESPUBLIKOJE EKONOMINIO CIKLO METU}

Santrauka. Čekijos ekonomiką pastaraisiais metais ženkliai paveikè ekonominè krizė. Ganètinai spartus ekonomikos augimas ir vèlesnè ekonomikos griūtis turèjo didelès ịtakos Čekijos darbo rinkai. Tačiau Čekijos regionų nedarbo lygio rodikliai, tiek bendri, tiek vyrų bei moterų, pasižymi dideliais skirtumais. Straipsnyje analizuojama, ar šie nedarbo lygio skirtumai tarp regionų padidèjo ekonominès krizés metu. Vis didejjantis atotrūkis tarp regionų rodo mažèjantị darbo rinkos lankstumą Čekijoje. Straipsnyje pateikiama dabartinès ekonominès padèties Čekijoje apžvalga ir atliktas Čekijos ir kitų ES šalių narių nedarbo lygio rodiklių palyginimas.

Tomas PAVELKA - Prague, University of Economics, Faculty of Business Administration, Department of Microeconomics, Ph.D., Doc., Ing. Research fields: labour market, macroeconomic theory.

Tomas PAVELKA - Mikroekonomikos katedros docentas, mokslų daktaras, verslo administravimo fakultetas, ekonomikos fakultetas, Prahos ekonomikos universitetas. Mokslinių tyrimų sritys: darbo rinkos, makroekonomikos teorija.

Tomas LÖSTER - Prague, University of Economics, Faculty of Informatics and Statistics, Department of Statistics and Economics, Ph.D., Ing. Research fields: multivariate statistical methods.

Tomas LÖSTER - Statistikos ir ekonomikos katedros doktorantas, informatikos ir statistikos fakultetas, Prahos ekonomikos universitetas. Mokslinių tyrimų sritys: daugiavariaciniai statistiniai metodai. 